\title{
Vitamin D and other extracellular factors in the control of growth
}

\author{
BY ISOBEL P. BRAIDMAN \\ Department of Medicine, University of Manchester, Hope Hospital, Eccles Old Road, Salford \\ M6 $8 H D$
}

\section{GROWTH FACTORS AND TISSUE GROWTH}

Since the first discovery of growth factors almost 30 years ago, the number of similar molecules which have been identified has increased with amazing rapidity. Our knowledge of their structure has enabled us to allocate them into groups, summarized in Table 1. All the growth factors included have bioactivity in standard in vitro assay systems. These are proliferation of 3T3 cells, derived from a fibroblast cell line, which divide only if growth factors are present (Pledger et al. 1977) and formation of transformed NRK kidney cell colonies in soft agar (Roberts et al. 1981). Most of these factors also increase cell proliferation in a variety of connective tissue cells. For example, insulin-related growth factor (IGF) stimulates division of fibroblasts (Hill et al. 1986), chondrocytes (Schalch et al. 1986) and osteoblasts or bone-forming cells (Bennett et al. 1984).

A picture thus emerges of an increasing number of molecules, which stimulate cell proliferation in certain test systems and a variety of cell types, often derived from connective tissues. There is little evidence to suggest, however, that they induce growth of these tissues de novo. This raises the question of whether tissue-specific growthpromoting molecules are required in this process, in place of, or in addition to, the known growth factors. Bone is a good illustration of these problems.

Table 1. Families of growth factors

1. Insulin-related growth factors

Insulin

IGF1

IGF2

SGF

2. Epidermal growth factors

EGF

TGF $\alpha$

3. Transforming growth factors

TGF $\beta$

Inhibin

4. Fibroblast growth factor

5. Platelet-derived growth factor 


\section{BONE CELL DIFFERENTIATION AND INTERACTIONS}

The major bone cell populations (osteoblasts and osteoclasts) are each derived from separate cell lines: osteoblasts are of mesenchymal origin whereas osteoclasts are of haemopoietic lineage (Kahn \& Simmons, 1975; Gothlin \& Ericsson, 1976). In fetal bone induction, there is massive proliferation of progenitor osteoblasts and a dramatic influx of osteoclasts onto the bone surface. The proliferation of each of these cell types may be under its own paracrine control, but it is also possible that the same factors act on both of them.

Throughout embryonic, postnatal and adult life, normal bone formation depends on a close relationship between osteoblast and osteoclast activity and differentiation. Bone formation and resorption always keep pace with one another and maintain normal calcium levels even at times of rapid bone remodelling, e.g. during the post-pubertal growth spurt. The mechanism for this coupling between the two cell types is still largely unknown. Current thinking favours the secretion of molecular signals by osteoblasts to stimulate osteoclast activity and maturation, and vice versa. It has been proposed that some of these signals are embedded in the bone matrix, and that osteoclasts, in particular, may respond to them at a later stage in bone remodelling.

\section{BONE GROWTH FACTORS}

Many different types of growth factors increase division of osteoblasts and related cells; IGF 1 and 2, fibroblast growth factor and platelet-derived growth factor all are effective in isolated osteoblasts, or in organ cultures of bone (Canalis \& Raisz, 1980; Ernst \& Froesch, 1987; Rodan et al. 1987). Transforming growth factor $\beta$ (TGF $\beta$ ) has different effects depending on the culture conditions used; under some, it stimulates cell proliferation whilst under others it is depressed (Pfeilschrifter $e t$ al. 1987; Guenther $e t$ al. 1988). These growth factors have all been considered to be important in bone development and candidates for either specific induction of bone formation or the coupling mechanism between osteoblasts and osteoclasts (for review, see Urist et al. 1983). TGF $\beta$ has been suggested (Mundy et al. 1988) as the coupling factor between osteoblasts and osteoclasts; the growth factor is thought to be secreted by osteoblasts, embedded in the bone matrix, where it is released by osteoclasts as they resorb the bone. During this process, TGF $\beta$ is activated by acidification and can then stimulate further osteoblast proliferation. There is, as yet, little direct evidence to support this suggestion.

With regard to bone formation, there is no obvious evidence for induction of mineralization in any of the systems discussed above. Without this, bone growth cannot occur. Bone morphogenic protein (BMP) is the only substance yet found which induces de novo osteogenesis (Urist et al. 1983). BMP is extracted from bone matrix and when injected subcutaneously cartilage first forms at the site of injection, which then becomes invaded by small capillary blood vessels. Mineralization then occurs, osteoblasts proliferate and differentiate and bone forms. The structure of this moiety has recently been elucidated by Wozney et al. (1989). They found that it has three components, one of which has partial homology with TGF $\beta$, another contains some TGF $\beta$ and epidermal growth factor sequences and a third which appears totally unique. We can now see that TGF $\beta$ may stimulate proliferation of osteoblast progenitors through its homology with the BMP components, but that the full range of events involved with bone induction could be due to the effects of the remainder of this molecular group. 


\section{RELATIONSHIP BETWEEN GROWTH FACTORS, PARACRINE AND ENDOCRINE SYSTEMS}

There are now numerous examples of molecules with structural homology with systemic hormones, or systemic hormones themselves which have paracrine or autocrine growth factor activity. For example the IGFs, which are related to insulin, stimulate proliferation of cartilage and other mesenchymal cells. The smaller sterols and steroid hormones, e.g. the glucocorticoids and 1,25-dihydroxycholecalciferol $\left(1,25(\mathrm{OH})_{2} \mathrm{D}_{3}\right)$ both have effects on cell proliferation which appear separate to their role as systemic hormones. We shall now consider this in more detail with $1,25(\mathrm{OH})_{2} \mathrm{D}_{3}$.

\section{THE VITAMIN D ENDOCRINE SYSTEM}

It is well established that $1,25(\mathrm{OH})_{2} \mathrm{D}_{3}$, the active metabolite of vitamin $\mathrm{D}_{3}$, has a major role in the systemic regulation of $\mathrm{Ca}$, and this has been reviewed extensively (DeLuca, 1979). Briefly, cholecalciferol is converted in the skin to 7-dehydrocholesterol by sunlight and, thereafter, in the liver to 25 -hydroxycholecalciferol. This is then metabolized to its active form, $1,25(\mathrm{OH})_{2} \mathrm{D}_{3}$ by the renal hydroxylase enzyme (25-hydroxycholecalciferol 1-hydroxylase; $E C$ 1.14.13.13). Synthesis of this enzyme is induced by parathyroid hormone (PTH), in response to a fall in circulating Ca levels. $1,25(\mathrm{OH})_{2} \mathrm{D}_{3}$ then acts via a classic steroid hormone receptor in the mucosal cells of the upper small intestine to initiate $\mathrm{Ca}$ resorption (Brumbaugh \& Haussler, 1975), thereby restoring normocalcaemia.

Other target tissues implicated in endocrine control of Ca levels are bone (Raisz et al. 1972; Reynolds et al. 1973) and kidney (Henry, 1979). The precise role of these tissues, particularly bone, in this system is uncertain. It is doubtful whether bone is as central to it as the intestine and this question will be re-examined later in the present article in the light of further evidence.

\section{EXTRA ENDOCRINE TARGET CELLS FOR $1,25(\mathrm{OH})_{2} \mathrm{D}_{3}$}

Over the past 10 years, a wide variety of tissues and cells have been found to have receptors for the sterol. Some of these are listed in Table 2 and most of them are apparently unconnected with the endocrine control of $\mathrm{Ca}$. The possibility that these are due to preparation of 'inactive' receptors or artifacts of preparation is incompatible with the observations that their presence is associated with biological effects of $1,25(\mathrm{OH})_{2} \mathrm{D}_{3}$ on the appropriate cell. Thus, the sterol decreases cell proliferation in malignant melanoma cells (Colston et al. 1981), enhances it in breast carcinoma cells (Freake et al. 1981 ), stimulates cell differentiation in monocytes and modifies synthesis of immune-cell growth factors.

\section{$1,25(\mathrm{OH})_{2} \mathrm{D}_{3}$ AND CELLS OF THE IMMUNE SYSTEM}

Some of the most detailed work on this aspect of $1,25(\mathrm{OH})_{2} \mathrm{D}_{3}$ function has been with monocyte and lymphocyte differentiation. Much useful information has been gained from studies with the cell lines derived from individuals with myeloid leukaemia, namely 
Table 2. Tissues and cells with receptors for and responses to 1,25-dihydroxycholecalciferol

\begin{tabular}{ll}
\hline \hline & Parathyroid gland \\
Kidney & Avian shell gland \\
Bone & Pituitary gland \\
Osteoblasts & Uterus \\
Osteosarcoma cells & Ovaries \\
Pancreas & Testes \\
Skin & Melanoma cells \\
Skin fibroblasts & Mammary gland \\
Breast cancer cells & Lymphocytes \\
Myeloma cells & Monocytes \\
\hline
\end{tabular}

mice ML cells and human HL60 cells. Sterol receptors have also been found on circulating leukocytes, almost exclusively in monocytic cells (Provvedini et al. 1983). Generally, $1,25(\mathrm{OH})_{2} \mathrm{D}_{3}$ depresses monocyte precursor cell proliferation and enhances differentiation to mature cells. It acts, therefore, unlike some of the growth factors, discussed earlier, since its effects are not confined simply to general cell proliferation. Thus, Miyaura et al. (1981), found that the sterol at $10^{-10}$ to $10^{-8} \mathrm{~mol} / \mathrm{induced} \mathrm{HL} 60 \mathrm{cell}$ maturation as seen by morphology, surface receptors for immunoglobins, and phagocytic activity. The concomitant presence of sterol receptors with enhanced differentiation of both cell lines are now well documented (Miyaura et al. 1983). Reitsma et al. (1983) described the molecular biology of these effects. They investigated oncogene transcription in HL60 cells and found that the level of C-myc expression was elevated. On exposure to $1,25(\mathrm{OH})_{2} \mathrm{D}_{3}$ its expression was markedly diminished, but the expression of genes for lysosomal enzymes (notably non-specific esterase) was raised, just before the activity of these enzymes increased and mature macrophage morphology was observed.

\section{$1,25(\mathrm{OH})_{2} \mathrm{D}_{3}$ AND BONE CELLS}

As with the discussion on growth factors, bone can be used to encapsulate the paradoxes inherent in these effects of the sterol. These are as follows: (1) Bone consists of several different cell types: do they all respond to the sterol and if so does the tissue have a constant uniform response? (2) Are these recently recognized targets for the sterol part of the mechanism for systemic control of $\mathrm{Ca}$, and if not how are the two aspects of $1,25(\mathrm{OH})_{2} \mathrm{D}_{3}$ action maintained side by side?

$1,25(\mathrm{OH})_{2} \mathrm{D}_{3}$ receptors are present in osteoblasts and some of their progenitor cells, and in general the sterol is thought to enhance mineralization and osteoblast differentiation. In organ culture systems, however, it stimulates bone resorption. Holtrop et al. (1981) have also shown that in thyroparathyroidectomized animals, the sterol enhances osteoclast numbers and activity. Moreover, $1,25(\mathrm{OH})_{2} \mathrm{D}_{3}$ would be expected to increase bone resorption in response to hypocalcaemia if bone were a target tissue in the endocrine control of $\mathrm{Ca}$. We will now consider the effects of the sterol on the two bone cell types in more detail; 


\section{Osteoblasts}

Receptors for the sterol have been found in intact bone (Manolagas et al. 1979), in cultured osteoblasts (Chen \& Feldman, 1981) and in osteosarcoma lines (Manolagas et al. 1980). Autoradiography of fetal bone has revealed the presence of nuclear receptors in osteoblasts and cartilage cells (Narbaitz et al. 1983). The biological responses of osteoblasts and related cells depend on the culture conditions; in some, cell proliferation and alkaline phosphatase $(E C$ 3.1.3.1) activities are increased, but in others they are decreased. The cell densities are crucial to this. In general the effects of the sterol are to increase differentiation of osteoprogenitor cells, thereby promoting mineralization and bone formation.

\section{Osteoclasts}

Previous studies have already indicated that there may be an increase in bone resorption promoted by $1,25(\mathrm{OH})_{2} \mathrm{D}_{3}$ (Reynolds et al. 1973). In our laboratory, we have reevaluated organ culture methods for fetal bone and the action of the sterol. We have found that in the fetal rat calvaria, mature osteoclasts only appear just before birth, i.e. at 21-22 d gestation. We wished to use cultured $19 \mathrm{~d}$ calvariae to investigate osteoclast differentiation, but found that when the bone was cultured in liquid culture medium, as used in previous studies (Reynolds et al. 1973), the activity of key enzymes in bone fell rapidly (Table 3 ) and that the morphology of the tissue quickly deteriorated. Improved methods of bone culture and rapid osteoclast detection were devised as follows.

\section{Table 3. The effect of different media on acid (EC 3.1.3.2) and alkaline phosphatase}

(EC 3.1.3.1) activities in cultured calvariae, measured in cryostat sections

(Mean values and standard deviations. Calvariae (19 d) were cultured in the range of liquid media shown. Cryostat sections of bone were reacted cytochemically, sections were randomized and cells selected for measurement. Each absorbance value is the mean derived from the average from each of three sections; fifteen to twenty cells were read from each section)

\begin{tabular}{|c|c|c|c|c|c|c|c|c|}
\hline \multirow[b]{3}{*}{ Medium } & \multicolumn{4}{|c|}{$\begin{array}{l}\text { Acid phosphatase in } \\
\text { osteoclasts (absorbance) }\end{array}$} & \multicolumn{4}{|c|}{$\begin{array}{c}\text { Alkaline phosphatase } \\
\text { in osteoblasts (absorbance) }\end{array}$} \\
\hline & \multicolumn{2}{|c|}{ Before culture } & \multicolumn{2}{|c|}{$\begin{array}{l}\text { After } 48 \mathrm{~h} \\
\text { culture }\end{array}$} & \multicolumn{2}{|c|}{ Before culture } & \multicolumn{2}{|c|}{$\begin{array}{l}\text { After } 48 \mathrm{~h} \\
\text { culture }\end{array}$} \\
\hline & Mean & SD & Mean & SD & Mean & SD & Mean & SD \\
\hline Medium $\alpha$ & 0.15 & 0.03 & $0.08 * * *$ & 0.04 & 0.31 & 0.04 & $0 \cdot 13^{* * *}$ & 0.05 \\
\hline $\begin{array}{l}\text { Minimal essential } \\
\text { medium }\end{array}$ & $0 \cdot 13$ & 0.04 & $0.06^{* * * *}$ & 0.03 & \multicolumn{2}{|c|}{ nd } & \multicolumn{2}{|c|}{ nd } \\
\hline Bigger's medium & 0.18 & 0.07 & $0.04^{* * *}$ & 0.02 & 0.28 & 0.03 & $0.14 * * *$ & 0.04 \\
\hline Trowell's medium & 0.21 & 0.04 & $0.06 * * *$ & 0.03 & 0.36 & 0.05 & $0.26^{* * *}$ & 0.04 \\
\hline Rotating cultures & 0.18 & 0.04 & $0.09 * * *$ & 0.04 & 0.38 & 0.06 & $0.21^{* * *}$ & 0.04 \\
\hline $21 \mathrm{~d}$ calvariae & 0.42 & 0.08 & & & 0.37 & 0.06 & & \\
\hline
\end{tabular}

nd, Not determined.

Significantly different from value before culture: $* * * P<0.001$. 


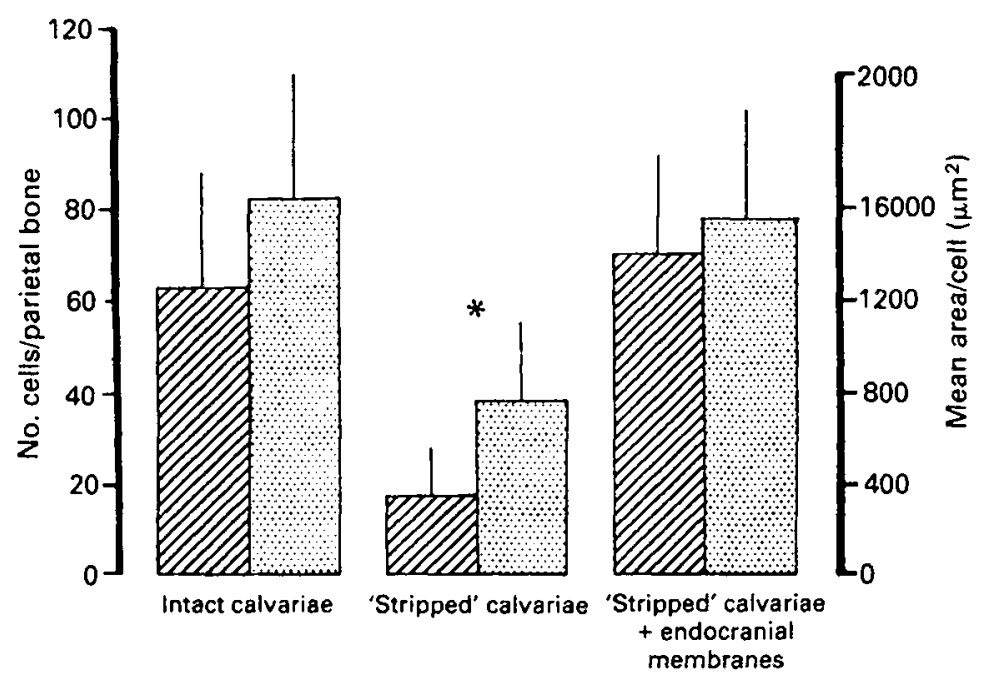

Fig. 1. Osteoclast precursors in endocranial membrane. Calvariae (19 d) were cultured for $48 \mathrm{~h}$ on collagen gels and reacted for acid phosphatase (EC 3.1.3.2) as described below. The bones were randomized and osteoclast numbers $(\mathbb{Z})$ and area ( $($ i $)$ were measured over the whole parietal region using computerized image analysis. The value for each experimental point was derived from three calvariae, and standard deviations are represented by vertical bars. Removal of the endocranial membranes ('stripped' calvariae), prevented the formation of osteoclasts in vitro, but many large cells were seen in 'stripped' calvariae co-cultured with their endocranial membranes. Mean value was significantly different from that for intact calvariae: ${ }^{*} P<0 \cdot 001$.

Culture conditions. Calvariae $(19 \mathrm{~d})$ were cultured on collagen gels $(1.5 \mathrm{mg} / \mathrm{ml})$ supplemented with $10^{-3} \mathrm{~mol}$ proline $/ 1,5^{-3} \mathrm{~mol}$ calcium $\beta$-glycerophosphate $/ 1$ and $1.5 \mu \mathrm{g}$ ascorbate/ml.

Osteoclast numbers and area. Whole calvariae which are high in osteoclasts, were reacted cytochemically for acid phosphatase $(E C 3.1 .3 .2)$ by incubating them with $2 \mathrm{mg}$ naphthyl ASBI phosphate $/ \mathrm{ml}$ in the presence of $50 \mathrm{~mm}$-tartrate for $20 \mathrm{~min}$ at $37^{\circ}$, followed by a 10 min incubation with Fast Blue RR. The blue granular chromogen is deposited specifically over the osteoclasts on the endocranial surface of the bone. The stain diffuses little over a $48 \mathrm{~h}$ period, on storage at $4^{\circ}$. Osteoclasts were counted and their area measured by computerized image analysis of the parietal region, using a MOP Videoplan IBAS system linked to an Olympus microscope.

Calvarial osteoclast recruitment in vitro. After culture for $48 \mathrm{~h}$ on the collagen gel system, many large osteoclasts were seen on the endocranial surface of the $19 \mathrm{~d}$ calvariae, mimicking osteoclast maturation in vivo. On examination of semi-thin sections of fixed bone, these cells appeared to be multinucleate and in association with areas of resorption. They also contracted off the calvarial surface in response to calcitonin.

Removal of the endocranial membranes from the inner surface of the bone ('stripped calvariae') prevented formation of these large osteoclasts in vitro (Fig. 1). They were, however, observed when the membranes were co-cultured with the 'stripped' calvariae, but not when $0 \cdot 22-\mu \mathrm{m}$ millipore filters were inserted between them.

Sources of calvarial osteoclasts. We tested various tissues for the presence of osteoclast precursor cells by co-culturing them with the 'stripped' calvariae on collagen. We thus 


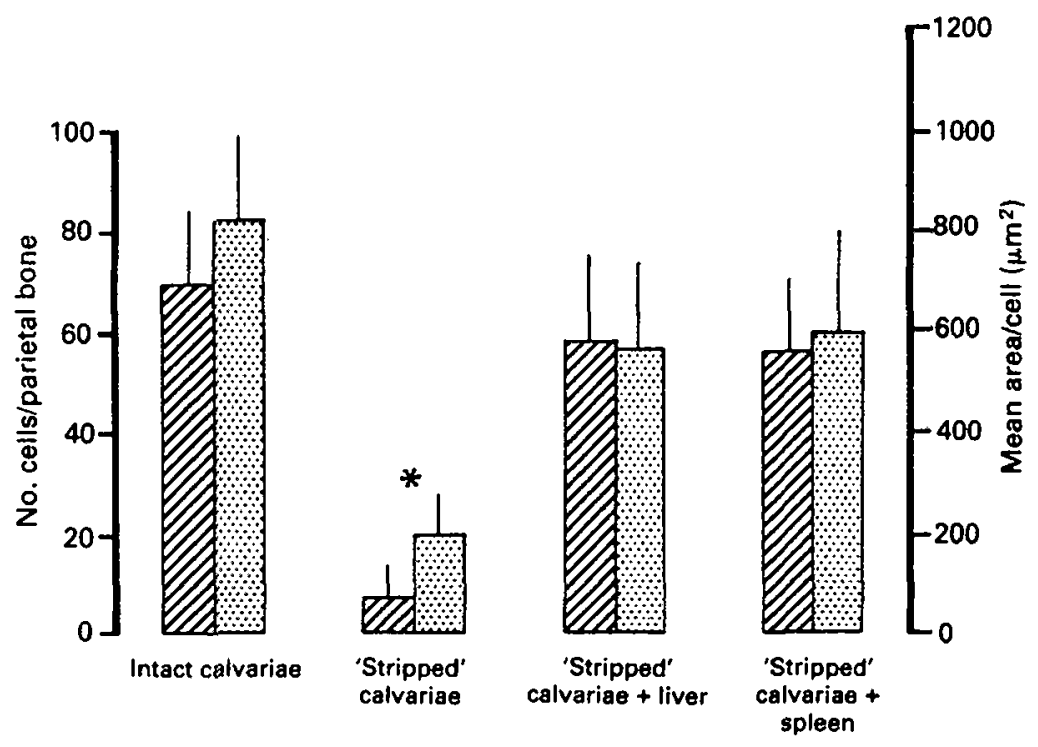

Fig. 2. Osteoclast precursors in fetal haemopoietic tissue. Calvariae (19 d) were cultured for $48 \mathrm{~h}$ on coilagen gels and reacted for acid phosphatase (EC 3.1.3.2) as described on p.96. The bones were randomized and

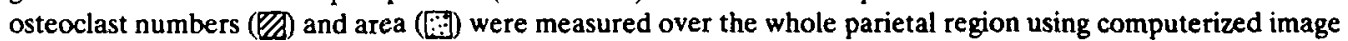
analysis. The value for each experimental point was derived from three calvariae, and standard deviations are represented by vertical bars. Co-culture of 'stripped' calvariae (endocranial membranes removed) with fetal liver and spleen resulted in the formation of significant numbers of osteoclasts, indicating that these tissues are rich in osteoclast precursors. Mean value was significantly different from that for intact calvariae: ${ }^{*} P<0.001$.

found that fetal liver and spleen (both haemopoietic tissues) and vascularized skin were all rich in osteoclast progenitor cells. Mesenchymal cells, derived from explants of skin, produced few mature cells (Fig. 2). Fetal, but not adult, blood contained a relatively high proportion of the precursors.

Stimulation of osteoclast maturation by $1,25(\mathrm{OH})_{2} \mathrm{D}_{3}$. Culture of intact $19 \mathrm{~d}$ calvariae with $10^{-8}$ or $10^{-9} \mathrm{~mol}$ sterol/l enhanced markedly the numbers of large osteoclasts over the first $24 \mathrm{~h}$. During the next $24 \mathrm{~h}$ there were no further increases in the sterol-treated bones, but numbers in the control calvariae rose so that results for all three groups were similar (Fig. 3).

We also wished to see if $1,25(\mathrm{OH})_{2} \mathrm{D}_{3}$ enhanced maturation of precursors in the fetal sources of these cells. 'Stripped' bones and fetal liver were each cultured with either medium or $10^{-9} \mathrm{~mol} \mathrm{sterol} / \mathrm{l}$ for $24 \mathrm{~h}$ and then co-cultured for a further $24 \mathrm{~h}$. Few large osteoclasts were found in co-cultures of medium-treated liver with medium-treated or sterol-treated 'stripped' calvariae. Significant osteoclast numbers were recorded in co-cultures of $1,25(\mathrm{OH})_{2} \mathrm{D}_{3}$-treated liver with medium- or sterol-treated 'stripped' bone (Fig. 4).

We conclude that endocranial membranes, which contain meningeal blood vessels, or any vascularized fetal mesenchymal tissues, are rich in osteoclast precursor cells. These cells are probably resident in the blood vessels during early development, and this is consistent with our finding that they are present in relatively high numbers in fetal, but not adult, blood. Fetal haemopoietic tissues are also good sources of osteoclast 

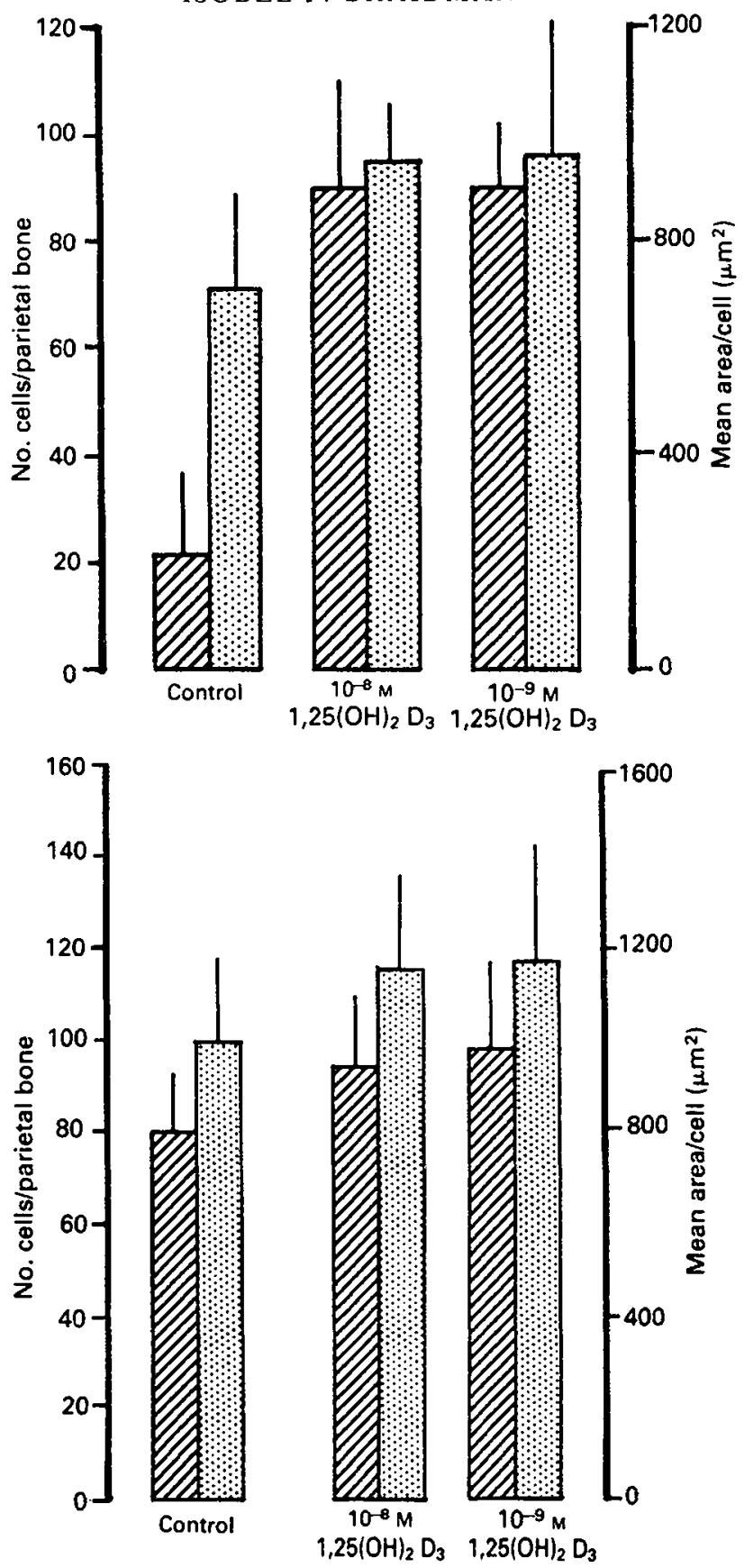

Fig. 3. Effect of 1,25-dihydroxycholecalciferol $\left(1,25(\mathrm{OH})_{2} \mathrm{D}_{3}\right)$ on osteoclast maturation in intact calvariae.

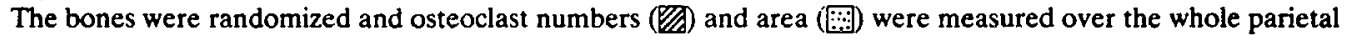
region using computerized image analysis. The value for each experimental point was derived from three calvariae, and standard deviations are represented by vertical bars. Intact $19 \mathrm{~d}$ calvariae were cultured in supplemented collagen alone, or with $10^{-8}$ or $10^{-9} \mathrm{~mol} 1,25(\mathrm{OH})_{2} \mathrm{D}_{3} /$ for either $(a) 24 \mathrm{~h}$ or $(b) 48 \mathrm{~h}$. After $24 \mathrm{~h}$ the sterol increased osteoclast formation over that of the controls $(P<0.001)$, but after $48 \mathrm{~h}$ there were no more increases in the bones cultured with $1,25(\mathrm{OH})_{2} \mathrm{D}_{3}$. Numbers in the control calvariae increased during this time, to those seen in the treated bones. 

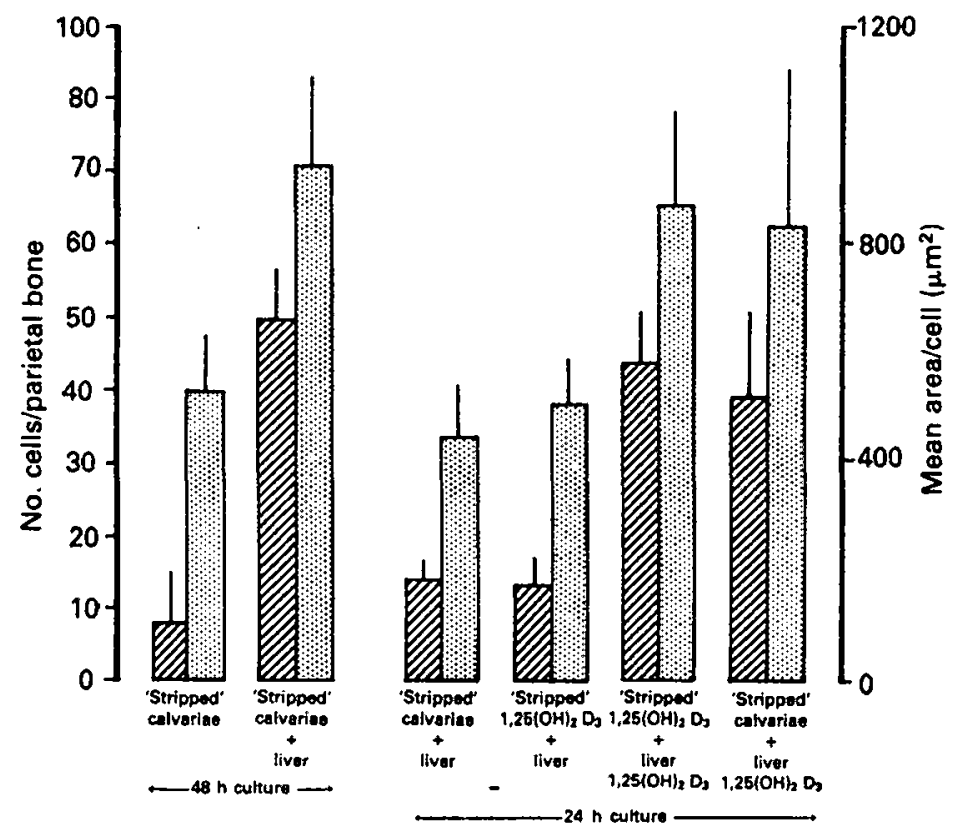

Fig. 4. Effect of 1,25-dihydroxycholecalciferol $\left(1,25(\mathrm{OH})_{2} \mathrm{D}_{3}\right)$ on osteoclast recruitment from haemopoietic tissues. 'Stripped' calvariae (endocranial membranes removed) and fetal liver were each cultured separately on control collagen gels or with $10^{-9} \mathrm{~mol} 1,25(\mathrm{OH})_{2} \mathrm{D}_{3} / \mathrm{h}$ for $24 \mathrm{~h}$. They were then co-cultured in the combination shown for a further $24 \mathrm{~h}$. 'Stripped' calvariae cultured alone or with fetal liver for $48 \mathrm{~h}$ were included as

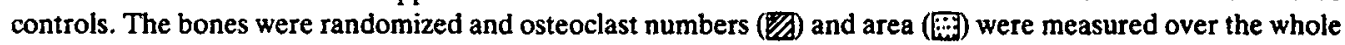
parietal region using computerized image analysis. The value for each experimental point was derived from three calvariae, and standard deviations are represented by vertical bars. Significant numbers of osteoclasts $(P<0.001$, in comparison with other groups) were seen only in those co-cultures where liver had been pretreated with the sterol.

precursors. $1,25(\mathrm{OH})_{2} \mathrm{D}_{3}$ enhanced the differentiation of the pool of osteoclast progenitor cells resident in the fetal calvaria. It also stimulated maturation of precursor cells in haemopoietic tissue, independently of any action it may have on other bone cells.

\section{BONE AND THE ENDOCRINE CONTROL OF CALCIUM HOMEOSTASIS}

It is unlikely that bone is part of the vitamin $\mathrm{D}_{3}$ endocrine system for mammals. Unlike avian species, where bone provides $40 \%$ of eggshell $\mathrm{Ca}$, mammalian skeletal structure is conserved and protected. It is more likely that bone cells are among the extra-endocrine targets for $1,25(\mathrm{OH})_{2} \mathrm{D}_{3}$. At certain stages of their differentiation, cells of osteoblast and osteoclast lineages are probably sensitive to low circulating concentrations of the sterol. The overall effect of the sterol on bone depends on its stage of remodelling; if there is an influx of osteoblast progenitors then bone formation may be stimulated, and likewise with osteoclasts. $1,25(\mathrm{OH})_{2} \mathrm{D}_{3}$ may thus be regarded as one of the modulators in the balance between bone formation and resorption, rather than a bone-resorbing agent per $s e$, possibly of particular importance in fetal development. 


\section{COMPATIBILITY OF ENDOCRINE AND EXTRA-ENDOCRINE FUNCTIONS OF}

THE STEROL

The 'extra'-endocrine functions of $1,25(\mathrm{OH})_{2} \mathrm{D}_{3}$ in modulating the differentiation of bone and other cell types have to be maintained simultaneously with its role in $\mathrm{Ca}$ homeostasis. It may be that like the growth factors the control of cell proliferation and differentiation by the sterol evolved early in unicellular organisms and is important in early embryonic development. As higher more complex multicellular organisms evolved, so did the need for systematic control of cell differentiation and function. These were based on the more simple systems already in existence. In the case of $1,25(\mathrm{OH})_{2} \mathrm{D}_{3}$, a major target tissue evolved in intestinal cells which was set at a relatively insensitive level, so that it responded only to large changes in circulating concentrations of the sterol. The other target cells (bone, monocytes, fibroblasts, etc.) retained their ability to respond to lower circulating levels of the sterol, since their receptors are set at a more sensitive level.

\section{REFERENCES}

Bennett, A., Chen, T., Feldman, D., Hintz, R. \& Rosenfeld, R. G. (1984). Characterization of insulin-like growth factor 1 receptors on cultured rat bone cells: regulation of receptor concentration by glucocorticoids. Endocrinology 115, 1577-1583.

Brumbaugh, P. F. \& Haussler, M. R. (1975). Specific binding of 1,25-dihydroxycholecalciferol to nuclear components of chick intestine. Journal of Biological Chemistry 250, 1588-1594.

Canalis, E. \& Raisz, L. G. (1980). Effect of fibroblast growth factor on cultured fetal rat calvaria. Metabolism 29, 108-114.

Chen, T. L. \& Feldman, D. (1981). Regulation of 1,25-dihydroxyvitamin $D_{3}$ receptors in cultured mouse bone cells. Journal of Biological Chemistry 256, 5561-5566.

Colston, K., Colston, M. J. \& Feldman, D. (1981). 1,25-dihydroxyvitamin $\mathrm{D}_{3}$ and malignant melanoma. Endocrinology 108, 1083-1086.

DeLuca, H. F. (1979). Recent advances in our understanding of the vitamin D-endocrine system Journal of Steroid Biochemistry 11, 35-54.

Ernst, M. \& Froesch, E. R. (1987). Osteoblast-like cells in serum-free methylcellulose medium form colonies: effects of insulin and insulin-like growth factor 1. Calcified Tissue International 40, 27-34.

Freake, H. C., Marocci, C., Iwasaki, J. \& MacIntyre, I. (1981). 1,25-dihydroxyvitamin $\mathrm{D}_{3}$ specifically binds to a human breast cancer cell line and stimulates growth. Biochemical and Biophysical Research Communications 101, 1131-1138.

Gothlin, G. \& Ericsson, J. L. E. (1976). The osteoclast. Clinical Orthopaedics and Related Research 120, 201-231.

Guenther, M. L., Cecchini, M. G., Elford, P. R. \& Fleisch, H. (1988). Effects of transforming growth factor $\beta$ upon bone cell populations grown in monolayer or semisolid medium. Journal of Bone and Mineral Research 3, 269-278.

Henry, H. L. (1979). Regulation of the hydroxylation of 25-hydroxyvitamin $\mathrm{D}_{3}$ in vivo and in primary cultures of chick kidney. Journal of Biological Chemistry 254, 2722-2729.

Hill, D. J., Crace, C. J., Strain, A. J. \& Milner, R. D. G. (1986). Regulation of amino acid uptake and DNA synthesis in isolated human fetal fibroblasts: effect of placental lactogen, somatomedin-C, MSA and insulin. Journal of Clinical Endocrinology and Metabolism 62, 753-760.

Holtrop, M. E., Co, K. A., Clark, M. B., Holick, M. F. \& Anast, C. (1981). 1,25-dihydroxyvitamin $\mathrm{D}_{3}$ stimulates osteoclasts in rat bones in the absence of parathyroid hormone. Endocrinology 108, 2293-2301.

Kahn, A. J. \& Simmons, D. J. (1975). Investigation of cell lineage in bone using a chimaera of chick and quail tissue. Nature 258, 325-327.

Manolagas, S. C., Haussler, M. R. \& Deftos, L. J. (1980). 1,25-dihydroxyvitamin $D_{3}$ receptor-like molecule in rat osteogenic sarcoma cell lines. Journal of Biological Chemistry 255, 4414-4417.

Manolagas, S. C., Taylor, C. M. \& Anderson, D. C. (1979). Highly specific binding of 1,25-dihydroxycholecalciferol in bone cytosol. Journal of Endocrinology 80, 35-39. 
Miyaura, C., Abe, E., Honma, M., Hozumi, M., Nishii, Y. \& Suda, T. (1983). Cooperative effect of 1,25-dihydroxyvitamin $\mathrm{D}_{3}$ and dexamethasone in inducing differentiation of mouse myeloid leukemic cells. Archives of Biochemistry and Biophysics 227, 379-385.

Miyaura, C., Abe, E., Kubiyashashi, T., Tanaka, H., Konno, K., Nishii, Y. \& Suda, T. (1981). 1,25dihydroxyvitamin $\mathrm{D}_{3}$ induces differentiation of human myeloid leukemia cells. Biochemical and Biophysical Research Communications 102, 937-943.

Mundy, G. R., Pfeilschrifter, J., Bonewald, L., Oreffo, J., Roodman, D. \& Seyedin, S. (1988). Proceedings of the 8th International Congress of Endocrinology. Kyoto: Japan. Abstr. 5-131.

Narbaitz, R., Stumpf, W. E., Sar, M., Huang, S. \& DeLuca, H. F. (1983). Autoradiographic localization of target cells for 1,25-dihydroxyvitamin $\mathrm{D}_{3}$ in bones from fetal rats. Calcified Tissue International 35, 177-182.

Pfeilschrifter, J., D'Souza, S. M. \& Mundy, G. R. (1987). Effects of transforming growth factor $\beta$ on osteoblastic osteosarcoma cells. Endocrinology 121, 212-218.

Pledger, W. J., Stiles, C. D., Antoniades, H. N. \& Scher, C. D. (1977). Induction of DNA synthesis in 3T3 cell by serum components. Proceedings of the National Academy of Sciences, USA 74, 4481-4485.

Provvedini, D. M., Tsoukos, C. D., Deftos, L. J. \& Manolagas, S. C. (1983). 1,25-Dihydroxyvitamin D3 receptors in human leukocytes. Science 221, 1181-1183.

Raisz, L. G., Trummel, C. L., Holick, M. F. \& DeLuca, H. F. (1972). 1,25-Dihydroxycholecalciferol-apotent stimulator of bone resorption in tissue culture. Science 175, 768-769.

Reitsma, P. H., Rothberg, P. G., Astrin, S. M., Trial, J., Bar-Shavit, Z., Hall, A. Teitelbaum, S. \& Kahn, A. J. (1983). Regulation of myc gene expression in HL-60 leukemia cells by a vitamin D metabolite. Nature 306, 492-494.

Reynolds, J., Holick, M. F. \& DeLuca, H. F. (1973). The role of vitamin D metabolites in bone resorption. Calcified Tissue Research 12, 295-301.

Roberts, A. B., Anzano, M. A., Lamb, L. C., Smith, J. M. \& Sporn, M. B. (1981). New class of transforming growth factor molecules potentiated by epidermal growth factors. Proceedings of the Academy of Sciences, USA 78, 5339-5344.

Rodan, S. B., Wesolowski, G., Thomas, K. \& Rodan, G. A. (1987). Growth stimulation of rat calvaria osteoblastic cells by acidic fibroblast growth factor. Endocrinology 121, 1917-1923.

Schalch, D. S., Sessions, C. M., Farley, A. C., Masakawa, A., Emlerr, C. A. \& Dills, D. G. (1986). Interaction of IGF1 with cultured rat chondrocytes. Endocrinology 118, 1590-1597.

Urist, M. R., DeLange, R. J. \& Finerman, G. A. M. (1983). Bone cell differentiation and growth factors. Science 220, 680-685.

Wozney, J. M., Rosen, V., Celeste, A. J., Mitsock, L. M., Whitters, M. J., Kriz, R. W., Hewick, R. M. \& Wang, E. A. (1989). Novel regulators of bone formation: molecular clones and activities. Science 242, $1528-1534$. 